\title{
Integrasi Pendekatan STEM (Science, Technology, Enggeenering and Mathematic) Untuk Peningkatan Keterampilan Berpikir Kritis Siswa Sekolah Dasar
}

\author{
Elisabeth Irma Novianti Davidi, Eliterius Sennen, Kanisius Supardi \\ irmadavidiparta@gmail.com, eliterius63@gmail.com, kanis.supardi17@gmail.com \\ Pendidikan Guru Sekolah Dasar, Universitas Katolik Indonesia Santu Paulus

\begin{abstract}
Integration Of STEM (Science, Technology, Engineering And Mathematic) Approache For Improving Critical Thinking Skills of Elementary School Students
\end{abstract}

\begin{abstract}
Improving the quality of education in Indonesia can be developed through the implementation of education reform. One form of educational reform can be done by using a learning approach that can assist teachers in producing experts using the STEM (Science, Technology, Engineering, and Mathematics) approach. The initial findings revealed only about $47.8 \%$ of elementary school students in Wae Ri'i sub-district (grade V) who still had not achieved satisfactory scientific and mathematical scores according to the minimum passing grade. This study aims to see the effectiveness of the STEM approach in improving the critical thinking skills of elementary school students in Wae Ri'i District. The research method used is an experimental design with Non Equivalent Control Group Design. The research subjects were elementary school students in five (5) elementary schools in Wae Ri'i District. The results shows the sig (2-tailed) value of Equal variances is assumed to be $0.000<0$, 05. Therefore, Ho is rejected and $\mathrm{Ha}$ is accepted, which means that there is a significant difference in critical thinking skills after students used the STEM-PBL approach, compared to innovative K13 approach. The average scores of the control class critical thinking skills for the pre-test and post-test were 38 and 79.5. The fixed coefficient is 0.676 and is significant at 0.000. This means that the correlation is positive. Therefore, learning with STEM approach is proven to be effective in improving the critical thinking skills of elementary school students in Wae Ri'i subdistrict.
\end{abstract}

Keywords: Learning, STEM Approach, Critical Thinking Skills, Elementary Students

Received date: 23 Juni 2019

Article Info

Revised date: 6 Januari $2021 \quad$ Accepted date: 19 Januari 2021

\section{PENDAHULUAN}

Kualitas sumber daya manusia dapat dilihat dari kemampuan lulusannya yang memiliki keterampilan, menguasai teknologi, serta memiliki pengetahuan yang luas dan keahlian profesional. Kenyatannya, Indonesia sebagai negara yang memasuki era persaingan bebas masih memiliki sumber daya manusia yang rendah. Kualitas sumber daya manusia yang rendah dipengaruhi oleh kualitas pendidikan di Indonesia masih tergolong rendah. Kemampuan siswa dalam menjawab soal penerapan dan penalaran lebihrendah daripada soal pemahaman. Hasil ini didukung dari riset PISA pada tahun 2015 yang terbit pada tahun 2016 yang menunjukkan bahwa Indonesia memiliki nilai rata-rata 403 dari rata-rata internasional 500 dan 501 dan data riset TIMSS tahun 2015, Indonesia menempati urutan ke 69 dari 76 negara yang terlibat (Bowel, Tracy \& Kemp, Garry. 2010: 57).

Peningkatan kualitas pendidikan di Indonesia bisa dikembangkan melalui penerapan reformasi pendidikan. Perubahan yang terjadi pada pembelajaran tradisional menuju ke pembelajaran yang lebih meningkatkan daya berpikir kritis disebut dengan reformasi pendidikan (Redhana, 2010: 148). Selaras dengan hal tersebut berdasarkan penelitian yang menunjukkan bahwa penerapan STEM dapat membantu mengembangkan pengetahuan, membantu menjawab pertanyaan berdasarkan penyelidikan, dan dapat membantu siswa untuk mengkreasi suatu pengetahuan baru (Permanasari, 2016: 24-31). Penerapan pendekatan pembelajaran STEM ini dapat membantu meningkatkan kemampuan berpikir kritis siswa. Berpikir kritis adalah berpikir dengan reflektif yang berfokus pada pengambilan keputusan 
Integrasi Pendekatan STEM (Science, Technology, Enggeenering and Mathematic) ... (Elisabeth Irma Novianti Davidi, Eliterius Sennen, Kanisius Supardi)

tentang apa yang diyakini dan apa yang harus dilakukan selanjutnya (Ennies, 2011: 17). Pendekatan pembelajaran STEM dengan mengintegrasikan keempat komponennya mampu menghasilkan aktivitas berpikir siswa yang berguna untuk membantu memunculkan berpikir kritis siswa yang ditandai dengan kemampuan memecahkan masalah, mengambil keputusan, menganalisis asumsi, mengevaluasi, dan melakukan penyelidikan.

Sekolah-sekolah dasar yang berada pada wilayah kecamatan Wae Ri'i sebagian besar telah menerapkan kurikulum K13. Kurikulum ini berlaku pada kelas 1 untuk kelas rendah, dan kelas 4 untuk kelas tinggi. Seyogyanya, dengan telah mengintegrasikan kurikulum K13 ini pada kegiatan pembelajaran, pihak sekolah telah yakin bahwa kompetensi pedagogik dan kapabilitas guru SD dalam penerapan K13 pada wilayah kecamatan Wae Ri'I ini sudah mencukupi. Para guru dianggap telah memiliki kemampuan dan keterampilan dalam menerapkan K13 di kelasnya. Namun kemampuan dan keterampilan guru tersebut beum cukup optimal dalam meningkatkan keterampilan berpikir kritis siswanya. Penggunaan strategi, pendekatan maupun metode yang digunakan hanya mampu meningkatkan keterampilan berpikir tingkat rendah saja. Alhasil, keterampilan berpikir kritis yang diharapkan ada pada diri siswa sekolaha dasar se-kecamatan Wae Ri'I belum menunjukan hasil yang memuaskan.

Hasil observasi yang dilakukan dapat diketahui bahwa kemampuan siswa dalam menanggapi pertanyaan dengan alasan, mengajukan pertanyaan pada saat belum mengerti materi masih kurang, begitu pun ketika siswa diminta untuk menganalisis suatu permasalahan, menyimpulkan permasalahan, dan mengevaluasi permasalahan masih kurang. Fakta ini mendukung akan temuan awal peneliti yang mendapati bahwa hanya sekitar 47,8\% siswa SD se-kecamatan Wae Ri'i (kelas V) masih belum mencapai nilai sains dan matematika yang memuaskan sesuai standar KKM. Sejalan dengan temuan tersebut, sebagai upaya untuk mengatasi dan meningkatkan kualitas sumber daya manusia melalui pendidikan maka diperlukan penerapan kemampuan berpikir kritis dengan menggunakan pendekatan STEM. Salah satu bentuk reformasi pendidikan dapat dilakukan dengan menggunakan pendekatan pembelajaran yang dapat membantu guru dalam menciptakan tenaga ahli yaitu pendekatan STEM (Science, Technology, Engeneering, and Mathematics). Pendekatan STEM ini adalah pendekatan yang merujuk kepada empat komponen ilmu pengetahuan, yaitu pengetahuan, teknologi, teknik, dan matematika. Berbasis pendekatan STEM inilah, maka tujuan penelitian ini adalah untuk mengetahui peningkatan keterampilan berpikir kritis siswa Sekolah Dasar sekecamatan Wae Ri'i.

\section{KAJIAN PUSTAKA}

\section{Pendekatan STEM (Science, Technology, Engeneering, and Mathematics)}

STEM merupakan akronim dari Science,Technology, Engineering, and Mathematics. Istilah ini pertama kali diluncurkan oleh National Science Foundation (NSF) Amerika Serikat (AS) pada tahun 1990-an sebagai tema gerakan reformasi pendidikan untuk menumbuhkan angkatan kerja bidang-bidang STEM, serta mengembangkan warga negara yang melek STEM (STEM literate), serta meningkatkan daya saing global Amerika Serikat dalam inovasi iptek (Hanover Research, 2011). Awalnya istilah yang digunakan adalah SMET namun diubah menjadi STEM untuk membantu mempromosikannya (Sanders, dalam Chesky dan Wolfmeyer, 2015: 26). Empat disiplin

STEM adalah Sains, Teknologi, Teknik, dan Matematika dan dapat diringkas sebagai berikut:

1) Sains memungkinkan kita untuk mengembangkan minat dan pemahaman tentang dunia kehidupan, materi, dan fisik serta mengembangkan keterampilan kolaborasi, penelitian, penyelidikan kritis, dan eksperimen

2) Teknologi mencakup berbagai bidang yang melibatkan penerapan pengetahuan, keterampilan, dan berpikir komputasi untuk memperluas kemampuan manusia dan membantu memenuhi kebutuhan dan keinginan manusia

3) Enggineering adalah keterampilan dan pengetahuan untuk mendesain dan mengkonstruksi mesin atau peralatan dan proses yang bermanfaat untuk memecahkan masalah dunia nyata

4) Matematika membekali kita dengan keterampilan yang diperlukan untuk menafsirkan dan menganalisis informasi, menyederhanakan dan menyelesaikan masalah, menilai risiko, membuat keputusan berdasarkan informasi dan memahami lebih lanjut dunia di sekitar kita melalui pemodelan masalah abstrak dan konkret (Departmen of Education and Skills, 2011). 
Sebagai pendekatan, STEM adalah pendekatan dalam pendidikan di mana Sains, Teknologi, Teknik, Matematika terintegrasi dengan proses pendidikan berfokus pada pemecahan masalah dalam kehidupan sehari-hari yang nyata serta dalam kehidupan profesional. Pendidikan STEM menunjukkan kepada peserta didik bagaimana konsep, prinsip, teknik sains, teknologi, teknik dan matematika (STEM) digunakan secara terintegrasi untuk mengembangkan produk, proses, dan sistem yang bermanfaat bagi kehidupan manusia.

Dalam pembelajaran sains, argumentasi disepakati sebagai komponen penting mengingat ilmu sains merupakan hasil konstruksi dari teori yang berisi penjelasan serta bukti yang mendukung penjelasan tersebut. Argumentasi menjadi sentral dari pendidikan khususnya dalam Pendidikan sains yaitu untuk membuat makna dan memberi efek penting pada pembelajaran (Yilmaz dkk.,2017). Hal tersebut didasari oleh beberapa pendapat yang menyatakan bahwa keterlibatan siswa dalam argumentasi ilmiah dapat meningkatkan pemahaman konseptual, epistemologis, dan metodologis tentang sains (Blanchard \& Sampson, 2012), juga mendukung siswa untuk enkulturasi ke dalam praktik sains (Dawson \& Venville, 2010). Terkait hal tersebut, peningkatan kualitas pembelajaran dengan menerapkan pendidikan STEM sebagai suatu pendekatan preventif diharapkan mampu membantu siswa mengintegrasikan aspek Science, Technology, Engineering dan Mathematics sehingga berimbas pada peningkatan keterampilan argumentasi. Sebelumnya, pendidikan STEM telah terbukti memiliki dampak positif pada prestasi siswa, sikap dan minat dalam pembelajaran dan motivasi mereka untuk. Selain itu, pendidikan STEM telah dilaporkan dapat meningkatkan keterampilan berpikir tingkat tinggi siswa dan literasi teknologi, melatih kemampuan pemecahan masalah pada siswa, inovator dan penemu yang baik (Stohlmann dkk., 2012), juga efektif untuk meningkatkan hasil belajar non-kognitif siswa seperti motivasi.

Pendidikan STEM bermakna memberi penguatan praktis pendidikan dalam bidang-bidang STEM secara terpisah, sekaligus lebih mengembangkan pendekatan pendidikan yang mengintegrasikan sains, teknologi, rekayasa, dan matematika dengan memfokuskan proses pendidikan pada pemecahan masalah nyata dalam kehidupan sehari-hari ataupun kehidupan profesi (Rosnawati, R. 2012: 14). STEM adalah pendekatan pembelajaran terpadu yang menghubungkan pengaplikasian di dunia nyata dengan pembelajaran di dalam kelas yang meliputi empat disiplin ilmu yaitu ilmu pengetahuan alam (sains), teknologi, hasil rekayasa, dan matematiknya.

Pendekatan STEM tidak hanya dapat diterapkan di sekolah dasar dan sekolah menengah, tapi juga dapat diterapkan di perkuliahan bahkan program doctoral. Pendekatan STEM menghubungkan pembelajaran dengan empat komponen pengajaran, yaitu science, technology, engeneering, and mathematics. Selaras dengan hal tersebut pendekatan STEM dapat dilaksanakan pada tingkat pendidikan formal/di dalam kelas dan tingkat satuan non formal/di luar kelas (Gonzalez \& Kuenzi. 2012: 17). Pembelajaran dengan menggunakan STEM dapat berupaya memunculkan keterampilan dalam diri siswa, misalnya kemampuan menyelesaikan persoalan dan kemampuanmelakukan penyelidikan. Keterampilan ini penting untuk membantu meningkatkan sumber daya manusia.

Pendukung pendekatan yang lebih terintegrasi untuk pendidikan STEM juga berpendapat bahwa mengajar STEM dengan cara yang lebih terhubung, terutama dalam konteks masalah dunia nyata, dapat membuat mata pelajaran STEM lebih relevan bagi siswa dan guru. Hal ini pada gilirannya dapat meningkatkan motivasi untuk belajar dan meningkatkan minat, prestasi, dan kegigihan siswa. STEM yang mengintegrasikan keempat disiplin ilmu dipercaya juga akan meningkatkan jumlah siswa yang mempertimbangkan karier di bidang yang terkait dengan STEM (Nathan, 2014).

Penggunaan pendekatan STEM dalam bidang pendidikan memiliki tujuan untuk mempersiapkan peserta didik agar dapat bersaing dan siap untuk bekerja sesuai bidang yang ditekuninya. Penelitian yang dilakukan oleh lembaga penelitian Hannover (2011: 8) menunjukkan bahwa tujuan utama dari STEM Education adalah sebuah usaha untuk menunjukkan pengetahuan yang bersifat holistik antara subjek STEM. Dalam konteks pendidikan dasar dan menengah, pendidikan STEM bertujuan mengembangkan peserta didik yang STEM literate (Bybee, 2013: 35), dengan rincian sebagai berikut.

1) Memiliki pengetahuan, sikap, dan keterampilan untuk mengidentifikasi pertanyaan dan masalah dalam situasi kehidupannya, menjelaskan fenomena alam, mendesain, serta menarik kesimpulan berdasar bukti mengenai isu-isu terkait STEM; 
Integrasi Pendekatan STEM (Science, Technology, Enggeenering and Mathematic) ...

(Elisabeth Irma Novianti Davidi, Eliterius Sennen, Kanisius Supardi)

2) Memahami karakteristik khusus disiplin STEM sebagai bentuk-bentuk pengetahuan, penyelidikan, dan desain yang digagas manusia;

3) Memiliki kesadaran bagaimana disiplindisiplin STEM membentuk lingkungan material, intelektual dan kultural,

4) Memiliki keinginan untuk terlibat dalam kajian isu-isu terkait STEM (misalnya efisiensi energi, kualitas lingkungan, keterbatasan sumberdaya alam) sebagai warga negara yang konstruktif, peduli, serta reflektif dengan menggunakan gagasan- gagasan sains, teknologi, rekayasa, dan matematika.

\section{Berpikir Kritis}

Pembelajaran yang mewajibkan siswa mengembangkan gagasan melalui langkah khusus dengan memanipulasi pengetahuan yang didapat yang menghasilkan pengetahuan baru disebut dengan kemampuan berpikir tingkat tinggi atau Higher Order Thinking Skill (HOTS). Kemampuan ini dapat muncul ketika siswa mampu menghubungkan berbagai informasi atau pengetahuan yang didapat dengan informasi yang telah ada sebelumnya untuk selanjutnya dikembangkan dengan memecahkan kesimpulan dari informasi tersebut (Rosnawati, 2012: 19)

Kemampuan berpikir tingkat tinggi meliputi kemampuan berpikir kritis, kemampuan berpikir kreatif dan kemampuan memecahkan masalah. Kemampuan dalam mengenal, menganalisis, mengkreasi, mengambil data secara obyektif dan mengevaluasi data dinamakan kemampuan berpikir kritis. Selanjutnya kemampuan dalam memecahkan masalah yang rumit dengan menciptakan gagasan baru dan belum terpublikasi dinamakan dengan kemampuan berpikir kreatif. Kemudian, kemampuan dalam memberikan jawaban atau solusi dalam suatu permasalahan dinamakan dengan kemampuan memecahkan masalah. Kemampuan berpikir tingkat tinggi (Higher Order Thinking) yang berfungsi untuk mempelajari pengetahuan dengan melakukan identifikasi masalah dan akhirnya menemukan pemecahan masalah yang kreatif.

Definisi berpikir kritis diartikan sebagai kemampuan untuk berpikir kembali, menguji kembali, merestrukturisasi pemikiran yang sudah ada. Hal ini dikarenakan pesatnya perkembangan zaman modern ini, yang menuntut masyarakat untuk selalu menyempurnakan keterampilannya agar dapat berfungsi dengan lebih efektif dan efisien dalam komunikasi dan interaksi global. Seseorang tidak dapat berfungsi atau melakukan sesuatu hanya dengan satu cara, bahkan akan selalu ada gejolak, dinamika yang tak terprediksi dan kompleks. Oleh karena itu dibutuhkan suatu kemampuan berpikir yang juga (Setyaningtiyas, 2019: 114). Dengan asumsi bahwa berpikir kritis adalah juga bagian dari keterampilan kognitif, maka keterampilan berpikir kritis menjadi suatu proses pengoptimalan kemampuan berpikir menuju tahapan yang lebih kompleks.

Mendukung asumsi tersebut Lau (2011: 34) menjelaskan “...Critical thingking is thinking clearly and rationally. It involves thinking precisely and systematically and following the rules of logic and scientific reasoning, among another things". Berpikir kritis menuntut individu untuk berpikir secara lebih jernih, rasional, tersistematis, logis dan memiliki alasan ilmiah mendasar yang memungkinkannya berbeda dari konsep berpikir metakognitif ataupun berpikir kreatif. Dengan prinsip berpikir yang lebih kompleks tersebut, konteks berpikir kritis menjadi semakin objektif dan mendasar. Hasil kajian dari pemikiran kritis, akan memungkinkan individu mengambil keputusan dan pilihan yang tepat sesuai yang dibutuhkan.

Pemikiran Wagner juga memberi pemahaman akan perlunya keterampilan berpikir kritis bagi anak usia SD bersifat mutlak ada. Dengan asumsi demikian maka dapat juga disimpulkan bahwa sesungguhnya keterampilan berpikir kritis ini telah dimiliki oleh siswa usia SD dengan rentang usia (6/7-11/12 tahun). Meskipun demikian, pada siswa sekolah dasar, keterampilan berpikir kritis tidak sekompleks konteks berpikir kritis untuk remaja atau orang dewasa. Hal ini dimungkinkan karena kemampuan berpikir anak SD masih pada tahap operasional konkret sesuai teori perkembangan Piaget. Mempertegas pemikiran Wargner, seorang psikog Erick Erickson (Bowel, et. All., 2010: 142) juga berpendapat bahwa anak pada usia SD awal pun telah memiliki kemampuan kompleks untuk menghadapi tantangan, meyelesaikan masalah dan menyelesaikan tugas, jika mereka diberi ruang dan kesempatan.

"Children between six and eight as being in the 'stage industry'ey like to create projects and want to

do job well. If they apportunities to apply the skills they are developing, they feel competent. By 
competent we mean sure enough of themselves to take a risk and to struggle with challengas ini order to reach a goal, solve a problem, or complete a risk".

Papalia \& Feldman (2014: 23) berpendapat bahwa pada tahap perkembangan operasional konkrit, pemahaman anak sudah lebih optimal dalam hal konsep spasial, sebab akibat, kategorisasi, penalaran induktif dan deduktif, konservasi dan angka. Hal ini berimbas pada kemampuan anak pada usia SD khusunya untuk siswa kelas V, telah ada pada pemikiran logis tetapi bukan abstrak; kemampuan mengambil keputusan secara lengkap sesuai urutan; pemahaman logika dari yang khusus ke umum; serta sedikit pemahaman dari logika umum ke khusus; serta kemampuan konservasi yang memungkinkan siswa dapat mengolah jawaban di kepala mereka. Dengan begitu, dasar untuk kemungkinan bahwa keterampilan berpikir kritis ini sesungguhnya telah ada dan dimungkinkan untuk berkembang lebih baik.

Implementasi STEM education dapat didukung oleh berbagai metode pembelajaran. STEM yang bersifat integratif memungkinkan berbagai metode pembelajaran dapat digunakan untuk mendukung penerapannya. Dalam pengintegrasian ini, metode Problem Based Learning $(\mathrm{PbL})$ dibutuhkan dalam pengaplikasian STEM pada pembelajaran kelas V SD dengan tema 8 subtema 3: Upaya Pelestarian Lingkungan.

Bentuk pengintegrasian dengan menggunakan metode $\mathrm{PbL}$ memiliki karakteristik sebagai berikut:

1) Membahas masalah lingkungan yang secara garis besar dapat dibagi menjadi pencemaran udara, tanah, dan air.

2) Melakukan kajian literatur tentang masalah lingkungan dari berbagai sumber (buku, artikel, jurnal penelitian, koran, dan lain-lain). Kajian literatur dilakukan secara individu. Hasil kajian ini kemudian dijadikan modal oleh setiap mahasiswa untuk berdiskusi dengan anggota kelompoknya.

3) Mendesain pemecahan masalah lingkungan berdasarkan bukti, hasil identifikasi, analisis, dan evaluasi terhadap masalah yang dibahas secara berkelompok. Setiap kelompok menuliskan sumber inspirasi dalam mendesain pemecahan masalah lingkungan tersebut. Menggagas cara praktis mengatasi masalah lingkungan yang dibahas oleh setiap kelompok, seperti mengatasi kebakaran hutan di Sumatera Selatan (dalam bentuk desain/prototipe). Desain/prototipe tersebut menjadi produk akhir dari pembelajaran pada tema 8, subtema 3 bagi siswa kelas V SD se-kecamatan Wae Ri'i.

\section{METODE PENELITIAN}

Penelitian ini menggunakan pendekatan kuantitaif dengan desain quasi experiment dan menggunakan jenis eksperimen the non-equivalent control group design. Pengambilan subyek secara random pada kelas ekperimen dan kelas Kontrol, pada 8 SD (SDI Kenda, SDI Lidang, SDI Ranggi, SDK Poco, SDK Poka, SDI Watu Alo, SDI Robo dan SDI Mbongos) dari 16 SD di wilayah kecamatan Wae Rii.

Pengumpulan data kuantitatif diperoleh dari nilai pre dan post test siswa, yang dilakukan dengan:

1) Pemberian pretest kepada seluruh sampel sebelum menerapkan pendekatan pembelajaran STEM.

2) Pemberian posttest kepada seluruh sampel setelah menerapkan pendekatan pembelajaran STEM.

Instrumen penelitian adalah suatu alat yang digunakan oleh peneliti untuk mengumpulkan data dan informasi tentang variabel obyektif untuk menjawab permasalahan yang terdapat dalam penelitian. Adapun istrumen yang digunakan pada penelitian ini adalah Lembar Tes Soal Uraian untuk mengetahui kemampuan berpikir kritis siswa Instrumen penilaian pada penelitian ini adalah berbentuk soal pilihan jamak dan uraian yang berlandaskan pada kisi-kisi instrumen penilaian pretest- posttest.

Selain itu, untuk melaksanakan pembelajaran digunakan RPP yang telah dirancang terintegrasi dengan pendekatan STEM. RPP adalah suatu rancangan pelaksanaan pembelajaran yang digunakan untuk mengukur tingkat ketercapaian kompetensi dasar dalam standar isi pada silabus. RPP juga berfungsi untuk memberikan gambaran mengenai rencana dalam melakukan pembelajan yang sesuai dengan pendekatan pembelajaran STEM. Data penelitian dianalisis dengan Analisisa N-Gain ; Uji Normalitas; Uji Homogenitas dan Uji Hipotesis (Independent sample T-test dan Paired Sample T-test). 
Integrasi Pendekatan STEM (Science, Technology, Enggeenering and Mathematic) ...

(Elisabeth Irma Novianti Davidi, Eliterius Sennen, Kanisius Supardi)

\section{HASIL PENELITIAN DAN PEMBAHASAN}

\section{Hasil Uji Prasyarat}

Hasil uji prasyarat dinilai dari hasil uji normalitas dan homogenitas data. Uji normalitas dan homogenitas data, adalah uji prasyarat yang harus dilakukan sebelum dilakukan uji hipotesis. Dengan bantuan aplikasi software SPSS 16, data diuji normalitas dan homogenitasnya. Data yang baik dan layak digunakan dalam penelitian adalah data yang memeiliki distribusi normal dengan ketentuan nilai signifikansi $>0.05$. Untuk homogenitasnya, atau suatu data dapat dikatakan homogen, jika nilai signifansinya $>0.05$.

Dari hasil analisis tersebut, dapat dilihat bahwa uji normalitas dan homogenitas menunjukan nilai signifikansi $>0.05$. Oleh karenanya dapat disimpulkan bahwa data berdistribusi normal dan Homogen.

\section{Hasil Uji Efektivitas}

Untuk mengetahui keefektivan pendekatan STEM dalam meningkatkan keterampilan berpikir kritis siswa SD, maka diukur dengan menggunakan teknik analisis tes pre dan post kelas eksperimen maupun kelas kontrol.

1) Uji Beda Keterampilan Berpikir Kritis

Uji t Berpasangan Kelas Eksperimen untuk Nilai Pretest-Posttest

Uji t berpasangan kelompok Eksperimen pada pretes-posttes dilakukan untuk mengetahui ada tidaknya perbedaan yang signifikan, rerata keterampilan berpikir kritis siswa sebelum dan sesudah pembelajaran dengan menggunakan pendekatan STEM. Pengujian tersebut dilakukan terhadap dua (2) hipotesis berikut.

Ho: Tidak ada perbedaan signifikan keterampilan berpikir kritis siswa kelompok kontrol antara sebelum dan sesudah pembelajaran dengan menggunakan pendekatan STEM.

Ha: Ada perbedaan signifikan keterampilan berpikir kritis siswa kelompok kontrol antara sebelum dan sesudah pembelajaran dengan menggunakan pendekatan STEM.

Tabel 1: Hasil Uji t Berpasangan pada Kelas Eksperimen

Paired Samples Correlations

\begin{tabular}{llccc}
\hline & N & Correlation & Sig. \\
\hline Pair 1 & $\begin{array}{l}\text { Pretes Eksperimen \& } \\
\text { Posttes Eksperimen }\end{array}$ & 103 & .676 & .000 \\
\hline
\end{tabular}

Paired Samples Test

\begin{tabular}{|c|c|c|c|c|c|c|c|c|c|}
\hline & & \multicolumn{5}{|c|}{ Paired Differences } & \multirow[b]{3}{*}{$\mathrm{T}$} & \multirow[b]{3}{*}{$d f$} & \multirow{3}{*}{$\begin{array}{l}\text { Sig. (2- } \\
\text { tailed) }\end{array}$} \\
\hline & & \multirow[b]{2}{*}{ Mean } & \multirow{2}{*}{$\begin{array}{c}\text { Std. } \\
\text { Deviation }\end{array}$} & \multirow{2}{*}{$\begin{array}{l}\text { Std. Error } \\
\text { Mean }\end{array}$} & \multicolumn{2}{|c|}{$\begin{array}{l}95 \% \text { Confidence } \\
\text { Interval of the } \\
\text { Difference }\end{array}$} & & & \\
\hline & & & & & Lower & Upper & & & \\
\hline Pair 1 & $\begin{array}{l}\text { Pretes } \\
\text { Eksperimen - } \\
\text { Posttes } \\
\text { Eksperimen }\end{array}$ & -41.971 & 11.749 & 1.158 & -44.267 & -39.675 & -36.254 & 102 & .000 \\
\hline
\end{tabular}

Berikut ini adalah ringkasan hasil uji tersebut:

1) Rerata nilai keterampilan berpikir kritis pada kelas kontrol untuk pre test dan post test adalah 38 dan 79.5 .

2) Koefisien korelasinya adalah 0.676 dan signifikan pada 0.000 . ini berarti koerelasinya positif.

3) Nilai t yang diperoleh adalah -36.254 dengan derajat bebasnya 102 dan signifikansi 2 ekor pada 0.000 .

4) Interval kepercayaan sebesar $95 \%$. 
Karena nilai t hitung < -t tabel $(-36.254<1.983)$, maka dapat dismpulkan bahwa, Ho ditolak dan Ha diterima. Ini berarti bahwa ada perbedaan signifikan keterampilan berpikir kritis siswa kelompok kontrol antara sebelum dan sesudah pembelajaran dengan menggunakan pendekatan STEM.

\section{Uji t Independent Kelas Kontrol-Eksperimen pada Post Tes}

Uji $t$ independen kelompok Kontrol-Eksperimen pada nilai post tes, dilakukan untuk mengetahui keterampilan berpikir kritis siswa baik pada kelompok kontrol maupun pada kelompok eksperimen sesudah dilakukan kegiatan pembelajaran dengan menggunakan pendekatan STEM. Dua (2) hipotesis yang diuji dalam pengujian tersebut adalah sebagai berikut.

Ho: Tidak ada perbedaan signifikan keterampilan berpikir kritis setelah pembelajaran antara siswa yang menggunakan pendekatan STEM dengan siswa yang menggunakan pendekatan inovatif $K 13$.

Ha: Ada perbedaan signifikan keterampilan berpikir kritis setelah pembelajaran antara siswa yang menggunakan pendekatan STEM dengan siswa yang menggunakan pendekatan inovatif K13.

Pengujian kedua hipotesis tersebut dilakukan dengan menggunakan bantuan perangkat aplikasi SPSS16. Hasil uji coba beda rata-rata nilai pretes kelompok kontrol (kelas B pada 5 $\mathrm{SD})$ dengan kelompok Eksperimen (kelas A pada $5 \mathrm{SD}$ ).

Tabel 2: Hasil Uji t Independent Post Tes Kelas Kontrol-Eksperimen Group Statistics

\begin{tabular}{llrrrr}
\hline & Kelas Postets & N & Mean & Std. Deviation & \multicolumn{2}{c}{ Mean } \\
\hline Keterampilan Berpikir & kelas Eksperimen & 103 & 79.50 & 14.305 & 1.410 \\
Kritis & Kelas Kontrol & 53 & 48.98 & 14.133 & 1.941 \\
\hline
\end{tabular}

Independent Samples Test

\begin{tabular}{|c|c|c|c|c|c|c|c|c|c|c|}
\hline & & \multicolumn{4}{|c|}{$\begin{array}{l}\text { Levene's } \\
\text { Test for } \\
\text { Equality of } \\
\text { Variances }\end{array}$} & \multicolumn{3}{|c|}{ t-test for Equality of Means } & \multirow{2}{*}{\multicolumn{2}{|c|}{$\begin{array}{l}95 \% \text { Confidence } \\
\text { Interval of the } \\
\text { Difference }\end{array}$}} \\
\hline & & & & & & \multirow{2}{*}{$\begin{array}{l}\text { Sig. (2- } \\
\text { tailed) }\end{array}$} & \multirow{2}{*}{$\begin{array}{c}\text { Mean } \\
\text { Difference }\end{array}$} & \multirow{2}{*}{$\begin{array}{l}\text { Std. Error } \\
\text { Difference }\end{array}$} & & \\
\hline & & $\mathrm{F}$ & Sig. & $\mathrm{T}$ & $d f$ & & & & Lower & Upper \\
\hline \multirow[t]{2}{*}{$\begin{array}{l}\text { Keterampilan } \\
\text { Berpikir Kritis }\end{array}$} & $\begin{array}{l}\text { Equal } \\
\text { variances } \\
\text { assumed }\end{array}$ & .206 & 651 & 12.669 & 154 & .000 & 30.514 & 2.408 & 25.756 & 35.272 \\
\hline & $\begin{array}{l}\text { Equal } \\
\text { variances } \\
\text { not assumed }\end{array}$ & & & 12.719 & 6.227 & .000 & 30.514 & 2.399 & 25.758 & 35.270 \\
\hline
\end{tabular}

1) Rerata nilai pre tes untuk kelas eksperimen dan kelas kontrol pada 5 SD se-kecamatan Wae Ri'i, masing-masing adalah 79 dan 48.

2) Nilai Sig. Levene's Test for Equality of Varians sebesar $0.651>0.05$, yang dapat diartikan bahwa varians data antara kelas A dan kelas B adalah homogen atau sama.

3) Nilai sig. (2-tailed) Equal variances assumed $0.000<0.05$, maka dapat disimpulkan Ho ditolak dan Ha diterima. 
Integrasi Pendekatan STEM (Science, Technology, Enggeenering and Mathematic) ...

(Elisabeth Irma Novianti Davidi, Eliterius Sennen, Kanisius Supardi)

4) Interval kepercayaan sebesar $95 \%$.

Berdasarkan uraian di atas, karena Ho ditolak dan Ha diterima maka dapat disimpulkan bahwa ada perbedaan yang signifikan keterampilan berpikir kritis setelah pembelajaran antara siswa yang menggunakan pendekatan STEM dengan siswa yang menggunakan pendekatan inovatif K13

\section{Deskripsi Data Indikator Keterampilan Berpikir Kritis}

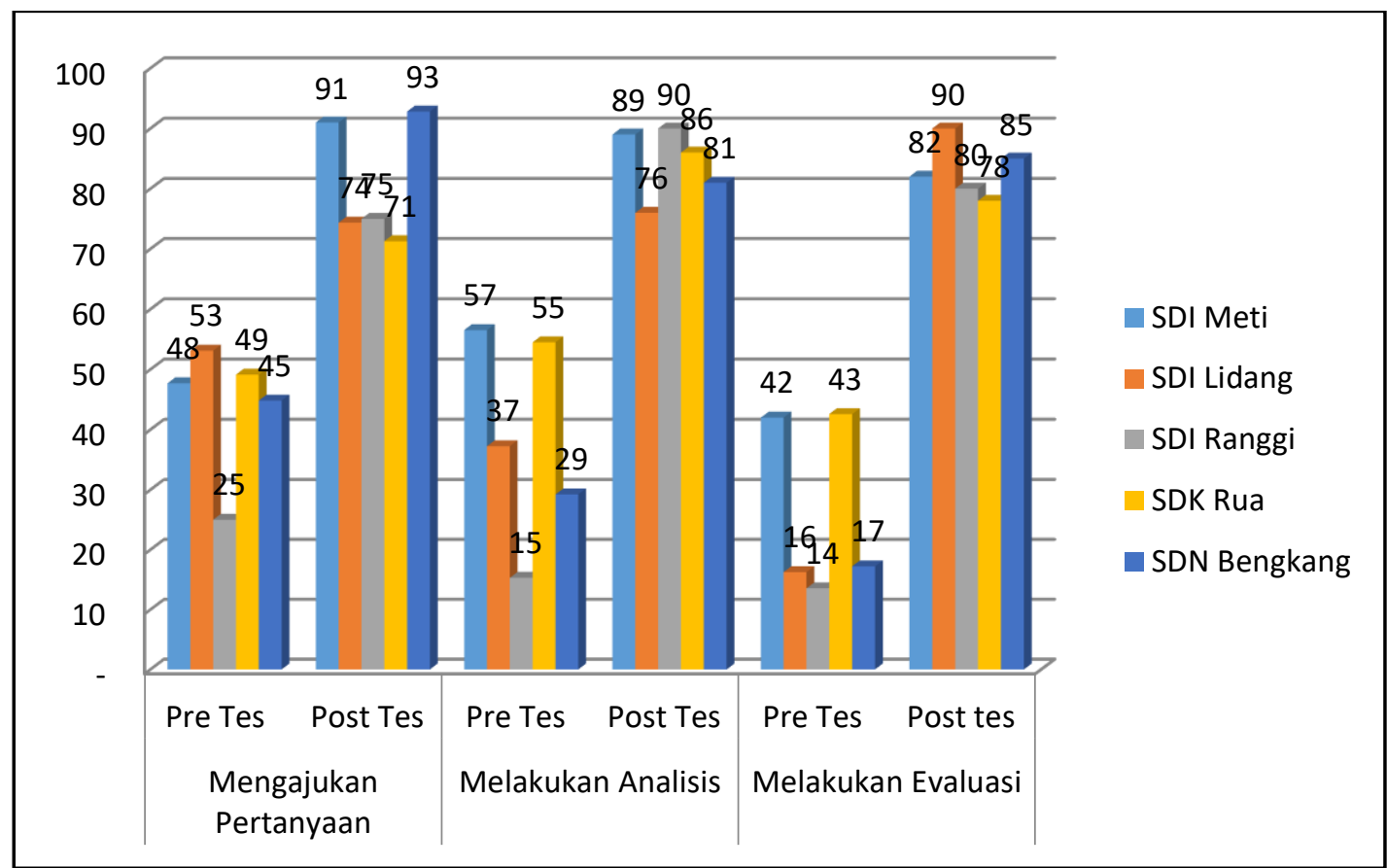

Bagan 1. Hasil Telaah Indikator Keterampilan Berpikir Kritis

\section{Pembahasan}

Peningkatan kualitas pembelajaran, khususnya pembelajaran berbasis Sains dan Matematika merupakan upaya yang tidak dapat ditunda-tunda lagi sejalan dengan berbagai tantangan yang dihadapi peserta didik saat ini, yaitu tantangan abad 21. Salah satu pendekatan pembelajaran yang dapat mengakomodir karakteristik pembelajaran abad 21 di atas adalah pendekatan Science, Technology, Engineering, and Mathematics (STEM). STEM merupakan suatu pendekatan di mana Sains, Teknologi, Enjiniring, dan Matematika diintegrasikan dengan fokus pada proses pembelajaran pemecahan masalah dalam kehidupan nyata. Pembelajaran STEM memperlihatkan kepada peserta didik bagaimana konsep-konsep, prinsip- prinsip sains, teknologi, enjiniring, dan matematika digunakan secara terintegrasi untuk mengembangkan produk, proses, dan sistem yang memberikan manfaat untuk kehidupan manusia (Hanouver. 2011). Untuk menyiapkan peserta didik Indonesia memperoleh keterampilan abad 21, yaitu keterampilan cara berpikir melalui berpikir kritis, kreatif, mampu memecahkan masalah dan mengambil keputusan serta cara bekerja sama melalui kolaborasi dan komunikasi, maka pendekatan STEM diadopsi untuk menguatkan implementasi Kurikulum Nasional (Kurikulum 2013.

Hasil penelitian Khoriyah (2018) menunjukan bahwa pembelajaran dengan pendekatan STEM terbukti dapat meningkatkan keterampilan berpikir kritis siswa SMA pada materi gelombang bunyi. Hasil penelitian menunjukkan bahwa nilai rata-rata $\mathrm{N}$-gain pada kelas eksperimen sebesar 0,63 dan kelas kontrol sebesar 0,35 dengan kategori sedang. Hal ini menunjukan bahwa pembelajaran gelombang bunyi pada kelas eksperimen yang diberi perlakuan dengan pendekatan STEM jauh lebih efektif menunjukan peningkatan keterampilan berpikir kritis daripada kelas control yang menggunakan pendekatan konvensional. Ini dimungkinkan karena pendekatan STEM mendorong siswa belajar aktif dan tanggap dalam melaksanakan berbagai eksperimen dan obeservasi dalam menemukan dan membuktikan konsep gelombang 
bunyi berbasis literasi sains, teknologogi, desain dan matematika. Dengan pembelajaran berbasis multiiterasi STEM ini, kemampuan dan keterampilan minds-on dan hands-on siswa menjadi lebih optimal yang memungkinkan kemampuan berpikir kritisnya semakin tajam.

Keterampilan mengajukan pertanyaan menjadi salah satu indikator penting dalam mengukur keterampilan berpikir kritis siswa SD. Dapat mengajukan pertanyaan yang tepat dan kritis merupakan buah dari proses aktif metakognisi untuk berpikir tentang pemikiran kita sendiri, sehingga muncul keraguaan atas fakta yang telah diperoleh (Fisher, 2009: 32). Hal ini dapat menjadi pintu awal untuk tahapan analisis fakta selanjutnya. Pendekatan STEM dalam pembelajaran di SD dengan tema upaya pelestarian lingkungan, memberi ruang bagi siswa untuk dapat mengajukan pertanyaan-pertanyaan kritis dan relevan mengenai kondisi lingkungan hidup yang dialami dan dilihatnya secara langsung maupun tak langsung. Dengan metode Problem based-Learning (PBL) STEM, siswa distimulasi melalui wacana, gambar dan kondisi yang kontekstual untuk dapat mengajukan pertanyaan kritis tersebut sebagai dasar analisis informasi dari masalah lingkungan hidup selanjutnya. Pertanyaan yang kritis juga menjadi focal point dalam metode PBL yang memungkinkan pertanyaan sebagai rumusan masalah untuk keperluan investigasi dan penelitian siswa. Model PBL-STEM juga dapat menstimulasi pembelajaran dengan masalah yang disajikan. Hal ini akan memungkinkan masalah menjadi spirit pembelajaran yang mengarahkan menuntun serta menggerakan siswa untuk mencari tahu, menemukan, mengkritisi dan menyelesaikannya. Hal ini sesuai dengan teori yang dikemukakan oleh(Baret, et all (2011: 76), bahwa pembelajaran dengan desain masalah yang distimulasi kepada siswa bisa dalam berbagai macam bentuk seperti sebuah skenario; kasus; tantangan; dilemma; ringkasan laporan; fenomena acak atau segala pancingan lainnya, dapat menggerakan siswa untuk dapat belajar lebih baik.

Indikator lainnya yang diteliti dari variabel keterampilan berpikir kritis adalah keterampilan menganalisis masalah atau argumentasi. Pendektan STEM dengan metode PBL memberi kesempatan bagi siswa SD di kecamatan Wae Ri'i (kelas eksperimen) untuk dapat menganalisis masalah lingkungan hidup yang dilihat (melalui wacana dan gambar) dan dialami langsung dalam keseharian siswa. Siswa dibimbing dan diarahkan untuk mampu menganalisis masalah yang dihadapi dengan menghadirkan berbagai solusi utama dan alternatif dalam upaya pengeloaan sampah sesuai standar 3R (Reduce, Reuse and Recycle), dan dapat memberikan argumentasi yang memadai dan relevan atas solusi tersebut. Keterampilan menganalisis masalah ini, memungkinkan ada kajian logis dan rasional suatu proses kognitif untuk dapat menentukan jalan keluar dan solusi praktis seperti apa yang dibutuhkan ketika menghadapi suatu permasalahan. Penelitian Tiwari et all, (2016: 549) juga menegaskan bahwa keterampilan berpikir kritis akan menjadi lebih optimal dengan desaian model pembelajaran PBL karena siswa menjadi lebih termotivasi dengan saling menstimulasi antar sesama mereka melalui pemikiran yang kritis dengan lebih fokus pada masalah; analisa yang tajam; pemahaman yang mendalam; pola pemikiran yang beragam, serta dapat mengambil keputusan yang benar. Oleh karenanya, optimalisasi pengetahuan dan kapabilitas individu maupun kelompok, menjadi hal penting yang sangat diperhatikan dalam model PBL.

Penelitian Thahir (2020) juga menegaskan bahwa pendekatan STEM juga memberi dampak dalam peningkatan sikap ilmiah dan pemahaman konseptual siswa pada materi fisika. Pengintegrasian dan penggalian mendalam asepek STEM (Science, Tecnology, Engineering and Mathematics) memberi kesempatan belajar dan meningkatan pengalaman belajar siswa dalam mengeksplor konsep-konsep Fisika dengan lebih detail namun bermakna. Pengeintrasian STEM juga mendorong siswa menjadi lebih ilmiah namun mudah mengelola semua pengalaman belajar yang abstrak yang diintegrasikan dengan kondisi factual sesuai konteks pembelajaran. Ha ini memungkinkan siswa menjadi lebih mudah menguasai konsep-konsep fisika tersebut.

Indikator variabel berpikir kritis terakhir yang diteliti adalah keterampilan melakukan evaluasi. Kelas eksperimen menunjukan perbedaan yang sangat signifikan daripada kelas kontrol dalam kemampuan mengevaluasi argumentasi dan solusi pada tema upaya pelestarian lingkungan. Kemampuan siswa SD untuk mengevaluasi tersebut memungkinkan siswa SD dapat menilai kembali keputusan atau solusi serta jalan keluar yang telah diambil dalam upaya mengolah sampah dengan konsep 3R. Keterampian mengevaluasi menjadi bagian dari keterampilan berpikir kritis. Hal ini disukung dengan pendapat Fisher (2009: 83) yang 
Integrasi Pendekatan STEM (Science, Technology, Enggeenering and Mathematic) ...

(Elisabeth Irma Novianti Davidi, Eliterius Sennen, Kanisius Supardi)

menyatakan bahwa berpikir kritis adalah interpretasi dan evaluasi yang terampil dan aktif terhadap observasi dan komunikasi, informasi dan argumentasi. Hal ini sejalan dengan penelitian Legant (2010: 17) yang mengaskan bahwa keterampilan berpikir kritis siswa dapat dilihat dari kemampuannya untuk mencari, menjelaskan, membandingkan, dan mengevaluasi berbagai pilihan informasi yang ada.

Oleh karena itu, pembelajaran dengan pendekatan STEM-PBL juga dapat memungkinkan siswa SD menyelesaikan masalah nyata dalam kehidupan dengan kajian yang lebih kritis untuk dapat menemukan solusi dan pemecahan masalah yang berkualitas (unknown, 2017: 23) Penelitian yang dilakukan oleh lembaga penelitian Hannover (2011: 23) menunjukkan bahwa tujuan utama dari STEM Education adalah sebuah usaha untuk menunjukkan pengetahuan yang bersifat holistik antara subjek STEM.

\section{SIMPULAN DAN SARAN}

Pembelajaran bagi siswa SD di kecamatan Wae Ri'i dengan menggunakan pendekatan STEMPBL menunjukan perbedaan yang signifikan jika dibandingkan dengan pembelajaran bagi siswa yang menggunakan pendekatan inovatif lainnya. Uji t independen kelompok Kontrol-Eksperimen pada nilai post tes, dilakukan untuk mengetahui keterampilan berpikir kritis siswa baik pada kelompok kontrol maupun pada kelompok eksperimen sesudah dilakukan kegiatan pembelajaran dengan menggunakan pendekatan STEM. Pengujian kedua hipotesis tersebut dilakukan dengan menggunakan bantuan perangkat aplikasi SPSS16. Nilai sig. (2-tailed) Equal variances assumed $0.000<0.05$, maka dapat disimpulkan Ho ditolak dan Ha diterima, yang berarti ada perbedaan yang signifikan keterampilan berpikir kritis setelah pembelajaran antara siswa yang menggunakan pendekatan STEM-PBL dengan siswa yang menggunakan pendekatan inovatif K13.

Uji t berpasangan kelompok Eksperimen pada pretes-posttes dilakukan untuk mengetahui ada tidaknya perbedaan yang signifikan, rerata keterampilan berpikir kritis siswa sebelum dan sesudah pembelajaran dengan menggunakan pendekatan STEM. Rerata nilai keterampilan berpikir kritis pada kelas kontrol untuk pre test dan post test adalah 38 dan 79.5. Koefisien korelasinya adalah 0.676 dan signifikan pada 0.000 . ini berarti koerelasinya positif. Nilai t yang diperoleh adalah -36.254 dengan derajat bebasnya 102 dan signifikansi 2 ekor pada 0.000 dengan interval kepercayaan $95 \%$. Karena nilai t hitung < -t tabel $(-36.254<1.983)$, maka dapat dismpulkan bahwa, Ho ditolak dan Ha diterima. Ini berarti bahwa ada perbedaan signifikan keterampilan berpikir kritis siswa kelompok kontrol antara sebelum dan sesudah pembelajaran dengan menggunakan pendekatan STEM, sehingga dapat disimpulkan bahwa pembelajaran dengan pendekatan STEM terbukti efektif dalam meningkatakan keterampilan berpikir kritis siswa sekolah dasar se-kecamatan Wae Ri'i.

Saran dalam penelitian ini ditujukan bagi peneliti selanjutnya agar dapat mengembangkan pendekatan STEM ini pada berbagai perangkat pembelajaran bagi siswa sekolah dasar. Diharapkan pengembangan STEM dalam perangkat pembelajaran mempermudah guru dalam menerapkan pendekatan STEM di kelasnya.

\section{UCAPAN TERIMAKASIH}

Ucapan terima kasih diberikan kepada para kepala sekoah dan guru di SDK Poco, SDK Timung, SDI Timung, SDN Bengkang dan SDI Norang yang telah membantu medukung pelaksanaan penelitian ini.

\section{DAFTAR PUSTAKA}

A Thahir, C Anwar, A Saregar, L Choiriah, F Susanti, \& A Pricilia. (2020). The Effectiveness of STEM Learning: Scientific Attitudes and Students' Conceptual Understanding. Journal of Physics: Conference Series, 1467(1), 1.

Barak, M., \& Dori, Y.J. (2005). Enhacing Under Graduate Students' Chemistry Understanding through Project-Based Learning in an IT Environment. Science Education. p.89.

Barrett, Terry \& Moore, Sarah. (2011). New Approaches to Problem Based Learning. New York: Routledge. 
Blanchard, M. R., \& Sampson, V. (2012). Assessment of the Ways Students Generate Arguments in Science Scientific Argumentation: Trends in Views and Practice. Journal of Research in Science Teaching, 1122-1148.

Bowel, Tracy \& Kemp, Garry. (2010). Critical Thinking: A Consice Guide. New York: Routledge.

Bybee, R. W., \& Landes, N. M. (1988). What research says about new science curriculums (BSCS). Science and Children, 25, 35-39. Critical Thinking about Values: A Quasi-Experimental Study: ResearchGate, 26(1), 4- Department of Education and Skills. 2011. National Strategy: Literacy and Numeracy for Learning and Life. Tersedia online: www.education.ie/en/Publications/Policy- Reports/lit_num_strategy_full.pdf

Dawson, V. M., \& Venville, G. (2010). Teaching strategies for developing students' argumentation skills about socioscientific issues in high school genetics. Research in Science Education, 133148.

Dewey, J. (1906). How We Think. Boston: DC Health. p.35

Fisher, Alec. (2009). Berpikir Kritis: Sebuah Pengantar. Jakarta: Erlangga.

Gonzalez, H. B. dan Kuenzi, J. J. (2012). Science, Technology, Engineering, and Mathematics (STEM) Education: A Primer. Congressional Research Service, 1-27 hlm. [Online], (https://fas.org/sgp/crs/misc/R42642.pdf), diakses Oktober 2018.

Hannover Research. (2011). K-12 STEM education overview.

Kirschner, P, et all., (2006). Why Minimal Guidance During Instruction Does Not Work: An Analysis of The Failure of Constructivist, Discovery, Problem Based Learning, Experential, and InquiryBased Teaching. Educational Psychologist. p. 75.

Lam, D. (2004). Problem-Based Learning: An Integration of Theory and Field. Journal of Social Work Education. p. 371.

Lau, Joe Y. F. (2011). An Introduction to Critical Thinking and Creativity. Canada: John Willey and Sons, Inc.

Legant, L. M. (2010). A case study examining critical thinking in an elementary service-learning project (Order No. 3411806). Available from ProQuest Dissertations \& Theses Full Text: The Humanities and Social Sciences Collection. (737542882). Retrieved from http://search.proquest.com/docview/737542882?accountid=25704.

Melzer, L. (2007). Executive Function in Education: From Theory to Practice. New York: Guilford. p. 145.

Nailul Khoiriyah, Abdurrahman Abdurrahman, \& Ismu Wahyudi. (2018). Implementasi pendekatan pembelajaran STEM untuk meningkatkan kemampuan berpikir kritis siswa SMA pada materi gelombang bunyi. Jurnal Riset Dan Kajian Pendidikan Fisika, 5(2), 53-62. https://eresources.perpusnas.go.id:2108/10.12928/jrkpf.v5i2.9977

Nathan, M. (2014). Integration in K-12 STEM Education: Status, Prospects, and an Agenda for Research. 121st ASEE Annual Conference \& Exposition.

Papalia, D. E \& Feldman, R.D. (2014). Menyelami Perkembangan Manusia-edisi 12. (Terjemahan Fitriana wuri Harayati). Jakarta: Salemba Humanika (Buku asli diterbitkan tahun 2104).

Permanasari, A. (2016). STEM Education : Inovasi dalam Pembelajaran Sains. Seminar Nasional Pendidikan Sains : Peningkatan Kualitas Pembelajaran Sains dan Kompetensi Guru Melalui Penelitian dan Pengembangan dalam Menghadapi Tantangan Abad-21, Universitas Pendidikan Indonesia, Bandung, 24-31 hlm. (Online), (http://jurnal.fkip.uns.ac.id/index.php/snps/ article/view/9810), diakses Juli 2018.

Pintrich, P., \& Schunk, D. (2002). Motivation in Education: Theory, Research, and Applications (2nd ed.). Upper Saddle River, NJ: Prantice Hall. p. 79. 
Integrasi Pendekatan STEM (Science, Technology, Enggeenering and Mathematic) ...

(Elisabeth Irma Novianti Davidi, Eliterius Sennen, Kanisius Supardi)

Redhana, I W. (2010). Pengaruh Model Pembelajaran Berbasis Peta Argumen terhadap Keterampilan Berpikir Kritis Siswa pada Topik Laju Reaksi. Jurnal Pendidikan dan Pengajaran, 43(17), 141-148 hlm. (Online), (https://ejournal.undiksha.ac.id/index.php/JPP/article/view/1721), diakses Agustus 2018.

Rosnawati, R. (2012). Enam Tahapan Aktivitas dalam Pembelajaran Matematika untuk Mendayagunakan Berpikir Tingkat Tinggi Siswa. Makalah disajikan dalam Seminar Nasional Revitalisasi MIPA dan Pendidikan MIPA dalam rangka Penguasaan Kapasitas Kelembagaan dan Profesionalisme Menuju WCU, Universitas Negeri Yogyakarta, Yogyakarta. (Online), (http://staff.uny.ac.id), diakses 12 September 2018.

Sanders, M. (2009). STEM, STEM education, STEMmania. The Technology Teacher, 68(4), 2026.

Setyaningtyas, E. (2019). Potensi Metode 1:4:P:C:R untuk Mengembangkan Keterampilan Berpikir Kritis dan Kreatif. Scholaria: Jurnal Pendidikan Dan Kebudayaan, 9(2), 111-121. https://doi.org/https://doi.org/10.24246/j.js.2019.v9.i2.p111-121

Stohlmann, M., Moore, T., \& Roehrig, G. (2012). Considerations for Teaching Integrated STEMEducation. Journal of Pre-College Engineering Education Research, 28-34.

Tiwari A, Lai P, So M, Kwan Y. A . (2016). Comparison of the effects of problem-based learning and lecturing on the development of students' critical thinking. Medical Education [serial online]. June 2006;40(6):547-554. Available from: Education Research Complete, Ipswich, MA. Accessed September 24, 2016.

Yilmaz, Y. A., Cakiroglu, J., Ertepinar, H., \& Erduran, S. (2017). The pedagogy of Argumentation in Science Education: Science Teacher's Instructional Practices. International Journal of Science Education, 1-22. 